\title{
Effects of Mulched Drip Irrigation on Soil Moisture and Groundwater Recharge in the Xiliao River Plain, China
}

\author{
Xiaohui Jin, Minjian Chen *, Yumiao Fan, Long Yan and Fang Wang \\ State Key Laboratory of Simulation and Regulation of Water Cycle in River Basin, China Institute of Water \\ Resources and Hydropower Research, Beijing 100038, China; xiaohui7360@126.com (X.J.); \\ fanyumiao1990@sina.com (Y.F.); longyan5942@sina.com (L.Y.); fangwangffww@sina.com (F.W.) \\ * Correspondence: minjch@sina.com; Tel.: +86-010-6878-5706
}

Received: 19 October 2018; Accepted: 27 November 2018; Published: 29 November 2018

\begin{abstract}
Mulched drip irrigation for maize cultivation has been widely implemented in the Xiliao River Plain in Northeast China in recent years. However, the effects of the change in irrigation method on soil water content and groundwater recharge in this area still remains uncertain. In this study, soil water content under mulched drip irrigation and flood irrigation was measured through field experiments. Soil water movement in the entire growing season under the two irrigation methods was simulated for the quantitative analysis of groundwater recharge by the Hydrus-2D model. Results showed that soil water content under mulched drip irrigation was generally larger than that of flood irrigation in the initial growth stage. However, an opposite trend was observed in the main growth stage. The simulated results indicated that the cumulative water fluxes of flood irrigation were greater than the values of mulched drip irrigation. Moreover, while infiltration depth under flood irrigation reached the maximum simulated depth $(400 \mathrm{~cm})$, infiltration depth under mulched drip irrigation was only $325 \mathrm{~cm}$. The results of this study showed that mulched drip irrigation reduced the infiltration depth and groundwater recharge to some extent in the Xiliao River Plain. Such results are helpful in determining the influence of mulched drip irrigation on groundwater and can be a reference for the maintenance of the sustainability of regional groundwater in the large-scale promotion of mulched drip irrigation.
\end{abstract}

Keywords: mulched drip irrigation; soil water content; groundwater recharge; Hydrus-2D

\section{Introduction}

Water resource shortage poses a problem for agricultural development in arid and semiarid regions. Mulched drip irrigation, which not only effectively relieves water paucity but also increases crop yield, has been widely used in such regions in recent years [1]. In China, mulched drip irrigation is widely used in cotton planting in the arid regions of Northwest China [2]. From 2012 to 2015, the "Water-saving and grain-increasing action" was implemented in Northeast China to encourage efficient water-saving irrigation. The area of cultivated land converted from the traditional irrigation method to mulched drip irrigation has reached 1.35 million $\mathrm{hm}^{2}$ [3]. This technology will provide an important guarantee for improving water use efficiency, ensuring food security, and realizing agricultural modernization [4].

Mulched drip irrigation technologies adopt the advantages of drip irrigation and film mulch, thus creating appropriate crop growth conditions in arable soil layers [5]. Film mulching efficiently reduces soil evaporation and increases the top soil temperature, thus maintaining suitable soil hydrothermal conditions [6,7]. On the other hand, the implementation of drip irrigation is often based 
on the actual growth status of crops, and fertilizer can be dissolved in water by drip irrigation systems. An appropriate irrigation schedule and effective fertilization method ensure that a small amount of water and fertilizer-through the mulched drip irrigation system in a steady flow-is delivered directly to the crop root zone in time. Therefore, mulched drip irrigation not only improves water and nutrient use efficiency, but also increases crop yield potential [8-10]. Moreover, this technology prevents soil deterioration due to salt accumulation in the surface soil and root zone during the growth period of crops, thereby creating a suitable environment for plant growth $[9,11]$.

The effects of mulched drip irrigation on economic crops have been investigated by many scientists [12-14] where their results generally indicate that mulched drip irrigation changes soil water content in the field, thus creating suitable water, fertilizer, gas, and heat conditions that are beneficial to crop growth and development $[15,16]$. Technical parameters of mulched drip irrigation such as the layout of plastic film and tube, dripper discharge, dripper spacing, frequency of drip irrigation, and irrigation amount have also been widely studied to ensure that the mulched drip irrigation system provides a good guarantee for crop growth. After the implementation of the "Water-saving and grain-increasing action", the effects of mulched drip irrigation on grain crops (mainly maize) have gradually attracted the interest of scientists. For instance, Qin et al. [4] investigated the effect of drip irrigation on soil water and crop evapotranspiration during 2014-2015 in Northwest China. Their results indicated that this technology reduced the total maize evapotranspiration over the entire growth period by less than $10 \%$. Zhang et al. [3] analyzed the effects of film mulching on field evapotranspiration, crop yield, and water use efficiency in a three-year field experiment in Northeastern China. They found that the total evapotranspiration under film mulching was $2.8-5.2 \%$ lower than without mulching, and the yield and water use efficiency separately increased by $5.9-8.8 \%$ and $10.7-13.1 \%$ in the field with film mulching.

In summary, whether for economic or food crops, most studies on mulched drip irrigation have usually been concerned with water use efficiency, yield, salinity, fertilizer, and technical parameters and are committed to the formulation of optimal irrigation schedules for increased yields. New characteristics of soil water movements may occur after the large-scale implementation of mulched drip irrigation. Moreover, regional groundwater recharges are expected to change, especially in semiarid areas dominated by the hydrologic cycle of rainfall-infiltration-evaporation. Unfortunately, previous studies have paid minimal attention to this aspect.

The current study investigated the spatial distribution of soil water in the soil profile under mulched drip irrigation and flood irrigation in the Xiliao River Plain in Northeast China. We simulated the soil water movement under the above two irrigation methods during the entire growth period of maize with the consideration of rainfall, irrigation, and evapotranspiration. We used water flux and infiltration depth as the basis for the comparison between the two irrigation methods with respect to infiltration and deep percolation fluxes. The main objectives of this study were to (1) describe the different distribution characteristics of soil water associated with mulched drip irrigation and flood irrigation, and (2) investigate the effects of mulched drip irrigation on infiltration and groundwater recharge.

\section{Materials and Methods}

\subsection{Experimental Site}

The field experiments were conducted in Kailu County, which is one of the main promotion areas for mulched drip irrigation. The station is located in the Xiliao River Plain in Northern China $\left(\mathrm{E} 121^{\circ} 23^{\prime}, \mathrm{N} 43^{\circ} 37^{\prime}\right)$ and has an elevation of $231 \mathrm{~m}$. The average annual rainfall is between 350 and $400 \mathrm{~mm}$, approximately $70 \%$ of which falls between July and August. Rainfall is an important source of groundwater recharge in the study area. The annual potential evaporation is between 1800 and $2000 \mathrm{~mm}$, which is mainly concentrated in the same period. The average annual temperature is $5.7^{\circ} \mathrm{C}$. The average annual groundwater table at the station is $6.1 \mathrm{~m}$ below the ground surface. 
The experimental crop was maize; maize seeds (Zheng-dan 958, Henan Academy of Agricultural Sciences, Zhengzhou, China) were sown at the beginning of May and harvested at the end of September each year, and the roots were distributed within $50 \mathrm{~cm}$ below the surface. The soil texture is presented in Table 1. Flood irrigation is the traditional irrigation method in the Xiliao River Plain. Thus, irrigation return flow is another important source of groundwater recharge. However, the irrigation method in some major grain-producing areas has been converted into mulched drip irrigation with the implementation of the "Water-saving and grain-increasing action".

Table 1. Soil texture of the experimental field.

\begin{tabular}{ccccc}
\hline \multirow{2}{*}{ Depth (cm) } & \multicolumn{3}{c}{ Particles Size Distribution (\%) } & \multirow{2}{*}{ Soil } \\
\cline { 2 - 4 } & Sand & Silt & Clay & \\
\hline $0-40$ & 53.1 & 36.4 & 10.5 & Loam \\
$40-80$ & 60.9 & 32.5 & 6.6 & Sandy loam \\
$80-150$ & 73.4 & 20.9 & 5.7 & Sandy loam \\
$150-200$ & 67.6 & 25.3 & 7.1 & Sandy loam \\
$>200$ & 85.5 & 8.9 & 5.6 & Loamy sand \\
\hline
\end{tabular}

\subsection{Design and Measurement}

The experiment was conducted in two separate plots belonging to the same village from the beginning of May 2016 to the end of September 2016. Plot I represented the flood irrigation area, which was approximately 86 hectares in size, and Plot II represented the mulched drip irrigation area, which was approximately 71 hectares in size. The distance between the two plots was less than $1 \mathrm{~km}$. The observation sites were set at the center of the two plots to ensure that the surrounding fields had the same irrigation conditions. Thus, the measurements could represent the two irrigation methods in this region. Time-domain reflectometry (TDR), which is based on measuring the dielectric constant of soil from the propagation velocity of a pulse traveling along an electromagnetic transmission line embedded in the soil [17], is an effective monitoring tool for soil water content [18,19]. Therefore, soil water content in both plots was measured by TDR probes (TRIME-PICO-IPH, IMKO, Ettlingen, Germany) during the maize growth period.

Three replications were adopted for each plot. In Plot I, each replication contained one soil profile located in the middle of the two rows of maize, and the spacing between two rows of maize was $60 \mathrm{~cm}$. In Plot II, the technology of "drip irrigation + ridge planting + plastic mulching" with maize planting in double rows at one width ridge was implemented, and each replication consisted of three soil profiles, namely, the middle position of ridge tillage (MRT), edge of plastic film (EPF), and middle position of bare furrow (MBF) (Figure 1). The spacing between two rows of maize was $40 \mathrm{~cm}$, and the three soil profiles were $30 \mathrm{~cm}$ apart from one another. Soil water content was measured at an interval of $10 \mathrm{~cm}$ in the vertical direction for each soil profile, and the maximum monitoring depth was $150 \mathrm{~cm}$. The cropping patterns and observation profiles under the two irrigation methods are shown in Figure 1. Soil water content in each soil profile was measured approximately every 10 days. One further measurement was added in the case of rainfall or irrigation events. At the start of the growing season, soil samples from the two plots were collected by auger in the vertical direction along the $4 \mathrm{~m}$ soil profiles with intervals of $10 \mathrm{~cm}$ at $0-2 \mathrm{~m}$ and $20 \mathrm{~cm}$ at $2-4 \mathrm{~m}$. The gravimetric soil water content of each soil sample was measured through the oven-dry method, and the measured value was converted into the volumetric soil water content by multiplying it with soil bulk density, which was determined by dividing the soil dry mass in the sampling ring with the sampling ring volume. 

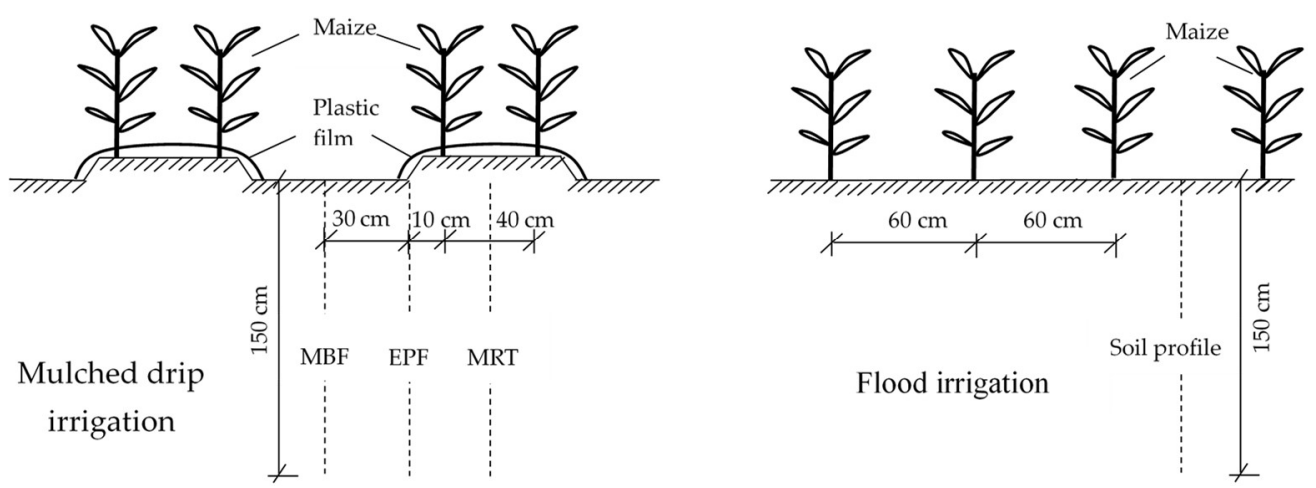

Figure 1. Schematic of the cropping patterns and observation profiles of soil water content.

Meteorological data were also indispensable for this study. Rainfall, temperature, humidity, wind speed, and solar net radiation were measured during the experimental period by an automatic weather station, which was located near the two experimental plots. The irrigation amounts and intervals under the two irrigation methods were based on the local practices. The irrigation levels were 228 and $381 \mathrm{~mm}$ for mulched drip irrigation and flood irrigation, respectively. The information of the irrigation events is given in Table 2.

Table 2. Schedule of irrigation events and amounts under mulched drip irrigation and flood irrigation.

\begin{tabular}{ccccc}
\hline Irrigation Method & \multicolumn{2}{c}{ Mulched Drip Irrigation } & \multicolumn{2}{c}{ Flood Irrigation } \\
\hline & Date & Amount $(\mathrm{mm})$ & Date & Amount $(\mathrm{mm})$ \\
& $2016 / 5 / 6$ & 19 & $2016 / 5 / 6$ & 31 \\
Schedule and & $2016 / 5 / 28$ & 43 & $2016 / 5 / 28$ & 72 \\
Amount & $2016 / 6 / 17$ & 43 & $2016 / 6 / 17$ & 72 \\
& $2016 / 7 / 10$ & 43 & $2016 / 7 / 10$ & 72 \\
& $2016 / 7 / 30$ & 40 & $2016 / 7 / 30$ & 67 \\
& $2016 / 8 / 8$ & 40 & $2016 / 8 / 8$ & 67 \\
\hline
\end{tabular}

\subsection{Establishment of Soil Water Flow Model}

In the soil water movement simulation, the amounts and distributions of rainfall, irrigation, and evapotranspiration were all considered during the entire growing season. Then, the difference in infiltration and groundwater recharge between the two irrigation methods was analyzed, along with the effects of mulched drip irrigation on groundwater recharge.

The Hydrus-2D model was used for the simulation of the soil water flow of the two irrigation methods under field conditions. The governing equation was a $2 \mathrm{D}$ version of the Richard equation for water flow [20], given as:

$$
\frac{\partial \theta}{\partial t}=\frac{\partial}{\partial x}\left[K(h) \times \frac{\partial h}{\partial x}\right]+\frac{\partial}{\partial z}\left[K(h) \times \frac{\partial h}{\partial z}\right]+\frac{\partial K(h)}{\partial z}-S
$$

where $\theta$ is the volumetric water content $\left(\mathrm{cm}^{3} / \mathrm{cm}^{3}\right) ; h$ is the pressure head $(\mathrm{cm}) ; K(h)$ is the unsaturated hydraulic conductivity $\left(\mathrm{cm} \cdot\right.$ day $\left.^{-1}\right) ; t$ is the time (day); $x$ and $z$ are the horizontal and vertical coordinates $(\mathrm{cm})$, respectively; and $S$ is the sink term $\left(\right.$ day $\left.^{-1}\right)$.

The sink term $S$, representing the volume of water removed per unit time from a unit volume of soil due to plant water uptake, was calculated as follows [21]:

$$
S\left(h, h_{\varphi}, x, z\right)=\alpha\left(h, h_{\varphi}, x, z\right) \times b(x, z) S_{t} T_{p}
$$

where $\alpha\left(h, h_{\varphi}, x, z\right)$ is a dimensionless function of the soil water $(h)$ and osmotic $\left(h_{\varphi}\right)$ pressure head $(0 \leq \alpha \leq 1)$ with the default setting; $S_{t}$ is the width of the soil surface associated with transpiration $(\mathrm{cm})$; 
$T_{p}$ is the potential evapotranspiration $\left(\mathrm{cm} \cdot \mathrm{day}^{-1}\right)$; and $b(x, z)$ is the root water uptake distribution function, which was calculated as follows [22]:

$$
b(x, z)=\left(1-\frac{x}{X_{m}}\right) \times\left(1-\frac{z}{Z_{m}}\right) \times e^{-\left(\frac{P_{x}}{X_{m}} \times\left|x^{*}-x\right|+\frac{P_{z}}{Z_{m}} \times\left|z^{*}-z\right|\right)}
$$

where $X_{m}$ is the maximum distance of root distribution in the horizontal direction, which was set to $20 \mathrm{~cm} ; Z_{m}$ is the maximum depth of root distribution in the vertical direction and was set to $50 \mathrm{~cm}, x^{*}$ and $z^{*}$ describe the locations of the maximum water uptake in the horizontal and vertical directions (cm), which were set to 0 and 10, respectively; and $P_{x}$ and $P_{z}$ are the empirical parameters of root asymmetry, which is normally set to 1.0 .

The domain geometry was defined as $180 \mathrm{~cm}$ in width and $400 \mathrm{~cm}$ in depth. The grid size of the simulation domain was $5 \mathrm{~cm}$ in the horizontal and vertical directions. For flood irrigation, the upper boundary condition was set as the atmospheric boundary (rainfall and evaporation), and free drainage was set as the bottom boundary. For mulched drip irrigation, the upper boundary condition was changed into a combination of atmospheric and variable flux boundary (rainfall, evaporation, and irrigation), and the irrigation was defined as the time-variable flux boundary to represent drip irrigation. The bottom boundary condition was the same as that in flood irrigation. The left and right boundary conditions for the two irrigation methods were set as no flux boundary.

Daily reference evapotranspiration $\left(E T_{0}\right)$ was calculated according to the Penman-Monteith model recommended by the Food and Agriculture Organization of the United Nations [23] as follows:

$$
E T_{0}=\frac{0.408 \Delta \times\left(R_{n}-G\right)+\gamma \times \frac{900}{T_{\text {mean }}+273} \times u_{2} \times\left(e_{s}-e_{a}\right)}{\Delta+\gamma \times\left(1+0.34 u_{2}\right)}
$$

where $E T_{0}$ is the reference evapotranspiration $\left(\mathrm{mmd}^{-1}\right) ; R_{n}$ is the net radiation $\left(\mathrm{MJ} \mathrm{m}^{-2}\right) ; G$ is the soil heat flux $\left(\mathrm{MJ} \mathrm{m}^{-2}\right.$ day $\left.^{-1}\right) ; \gamma$ is the psychometric constant $\left(\mathrm{kPa}^{\circ} \mathrm{C}^{-1}\right) ; T_{\text {mean }}$ is the daily mean air temperature; $u_{2}$ is the average wind speed at the height of $2 \mathrm{~m}\left(\mathrm{~m} \mathrm{~s}^{-1}\right) ; e_{s}$ is the saturation vapor pressure $(\mathrm{kPa}) ; e_{a}$ is the actual vapor pressure $(\mathrm{kPa})$; and $\Delta$ is the slope of the saturation vapor pressure-temperature curve $\left(\mathrm{kPa}^{\circ} \mathrm{C}^{-1}\right)$.

Potential evaporation and transpiration are required as inputs in Hydrus-2D. These were calculated according to the measured leaf area index ( $L A I)$ and crop coefficient of maize $\left(k_{c}\right.$, as shown in Figure 2), as follows:

$$
\begin{gathered}
E T_{c}=k_{c} \times E T_{0} \\
T_{p}=E T_{c} \times\left(1-e^{-k L A I}\right) \\
E_{p}=E T_{c} \times e^{-k L A I}
\end{gathered}
$$

where $E T_{c}$ is the evapotranspiration of the crop; $T_{p}$ is the potential transpiration; $E_{p}$ is the potential evaporation; and $k$ is the attenuation coefficient of canopy radiation. 


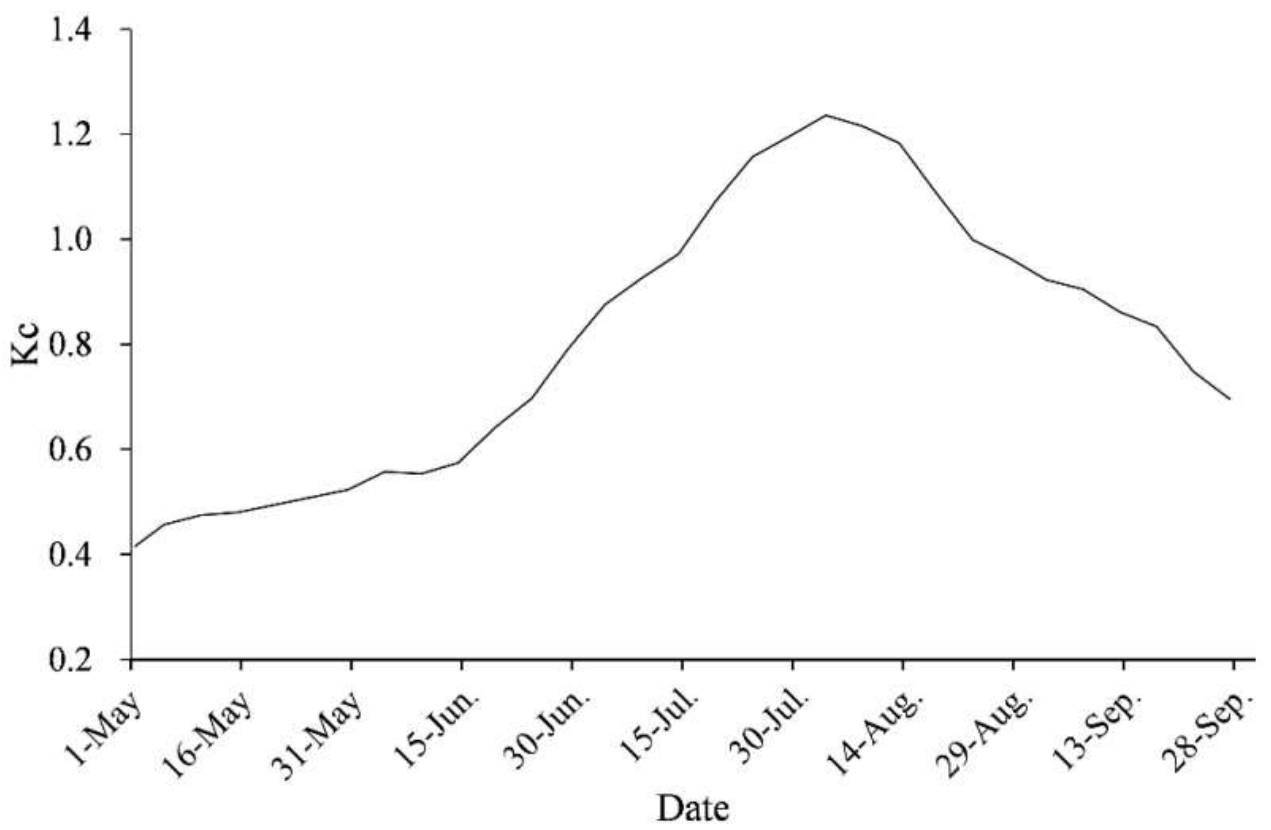

Figure 2. Crop coefficients of maize in the Xiliao River Plain.

Soil hydraulic properties were described by the van Genuchten-Mualem model at the experimental site $[24,25]$. The inverse module was used for the optimization of soil hydraulic parameters according to the measured soil water content at different depths [10]. Calibration and validation are two important processes for the use of Hydrus-2D. The calibration process was carried out using measured soil water content under flood irrigation. Then, under mulched drip irrigation, the model was validated using the calibrated soil hydraulic parameters.

In the simulation of soil water movement in each irrigation method during the growing season, the initial conditions of soil water content were defined according to the values of the measured data at the start of the growing season.

\subsection{Data Analysis}

In both irrigation methods, the value of the soil water content was the average of three corresponding replication data. For mulched drip irrigation, the values of soil water content for each replication were averaged by the three soil profile data, and the values of soil water content for each soil profile (MRT, EPF, and MBF) were averaged by the three corresponding replication data. For the purpose of comparing the difference in soil water content at different depths in the vertical direction under the two irrigation methods, soil water content in the soil profile was divided into three zones for statistics in the vertical direction according to the measurements obtained from the in situ experiment. The zones were designated as follows: the direct-influence zone of maize roots $(0,50 \mathrm{~cm})$ where maize roots directly absorb soil moisture to supply their own growth; the indirect-influence zone of maize roots $(50,100 \mathrm{~cm})$ where soil water movement is affected by the water potential difference caused by the water consumption of the upper layer; and the subtle-influence zone of maize roots $(100,150 \mathrm{~cm})$ where maize roots do not considerably deplete soil moisture.

Infiltration depth and soil water flux are important indicators for illustrating the status of infiltration and potential groundwater recharge. In this study, infiltration depth at a certain time was defined based on the difference between the soil water content at a certain time and the initial soil water content of the soil profile. When the difference in soil water content between the two moments was nearly zero, the corresponding depth was considered the infiltration depth. Soil water flux at different depths could be obtained through the Hydrus-2D simulation by setting mesh lines. 
The agreement between the simulated and measured data was evaluated by mean absolute error $(M A E)$, normalized root mean square error (NRMSE), and the Nash-Sutcliffe model efficiency (NSE) as follows:

$$
\begin{array}{r}
\text { MAE }=\frac{\sum_{i=1}^{N}\left|M_{i}-S_{i}\right|}{N} \\
\text { NRMSE }=\frac{\sqrt{\frac{1}{N} \sum_{i=1}^{N}\left(M_{i}-S_{i}\right)^{2}}}{\bar{M}} \\
\text { NSE }=1-\frac{\sum_{i=1}^{N}\left(M_{i}-S_{i}\right)^{2}}{\sum_{i=1}^{N}\left(M_{i}-\bar{M}\right)^{2}}
\end{array}
$$

where $M_{i}$ and $S_{i}$ are the $i$ th measured and model simulated values for soil water content, respectively; $N$ is the number of observations; and $\bar{M}$ is the mean values of the measured values.

\section{Results}

\subsection{Variations in Measured Soil Water Content}

Soil water content is an important factor that affects plant growth and is a critical factor that affects infiltration. Based on the field experiment results, we obtained the variations in soil water content under mulched drip irrigation and flood irrigation during the growing season of maize, which was divided into the initial growth stage (early May to late June) and the main growth stage (early July to late August). These two stages corresponded to the period before and after the elongation stage of maize.

The soil water content under the two irrigation methods are shown in Figure 3. In the initial growth stage, the difference in soil water content between mulched drip irrigation and flood irrigation was mainly within a depth of $1 \mathrm{~m}$. The soil water content under mulched drip irrigation was greater than that of flood irrigation, and the relative difference between the two irrigation methods was $7.9 \%$ within $1 \mathrm{~m}$. In particular, within $50 \mathrm{~cm}$, the relative difference between the two irrigation methods was $9.9 \%$. At depths of $50-100 \mathrm{~cm}$ and $100-150 \mathrm{~cm}$, the relative difference between the two irrigation methods were $5.9 \%$ and $3.5 \%$, respectively. In the main growth stage, the soil water content along the $150 \mathrm{~cm}$ soil profile under mulched drip irrigation was smaller than the value under flood irrigation. Specifically, the relative difference between the two irrigation methods were $6.5 \%, 7.3 \%$, and $13.1 \%$ at depths of 0-50 cm, 50-100 cm, and 100-150 cm, respectively. In short, the soil water content under mulched drip irrigation was generally greater than that of flood irrigation in the initial growth stage. However, an opposite trend was observed in the main growth stage. 

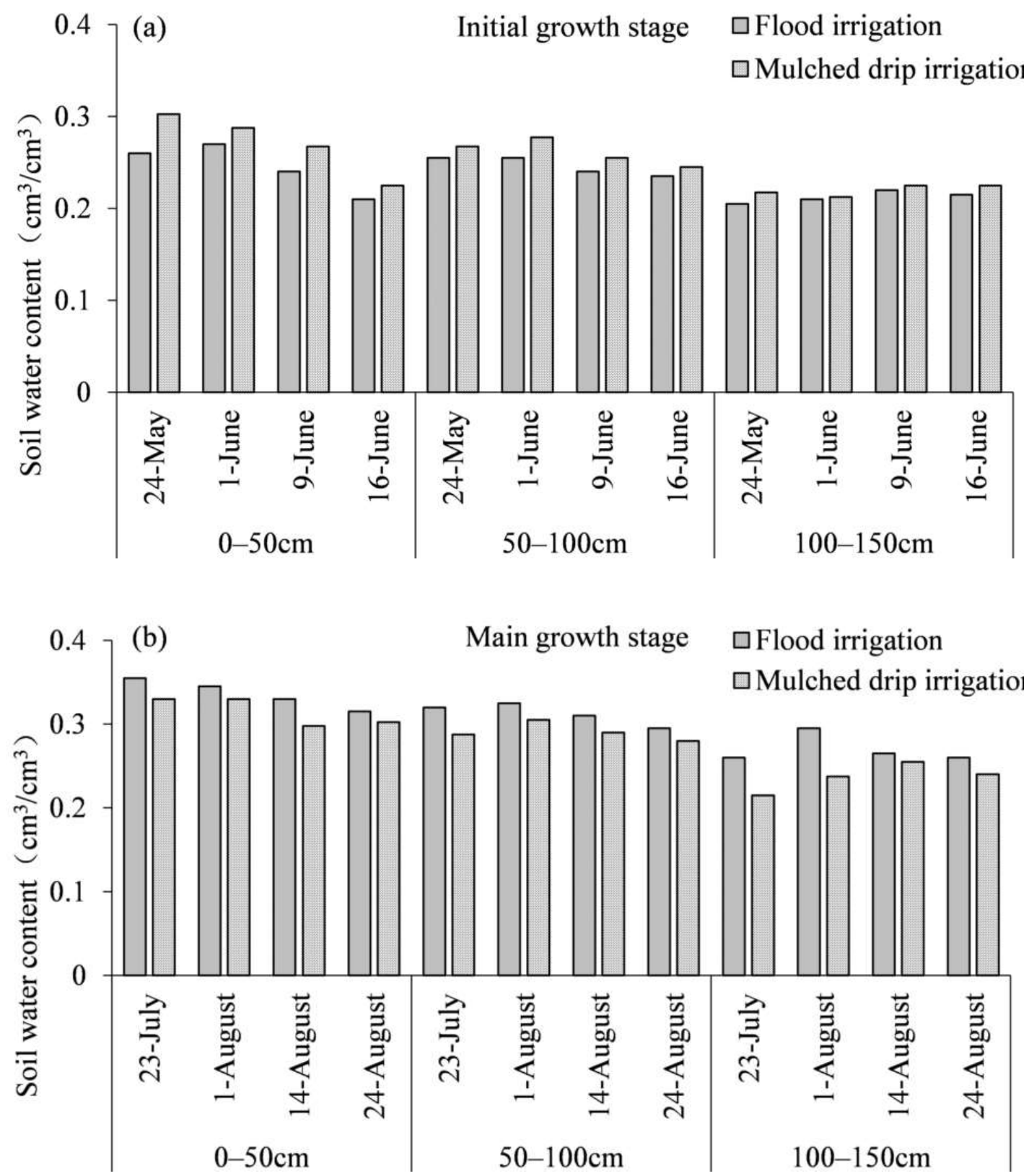

Figure 3. Comparison of soil water content between mulched drip irrigation and flood irrigation.

\subsection{Model Calibration and Validation}

The measured soil water content under flood irrigation was used for calibration and that under mulched drip irrigation was used for validation. Based on the model calibration results, the optimized soil hydraulic parameters are summarized in Table 3 . The simulated and measured values for soil water content under the two irrigation methods at different soil depths are shown in Figure 4. The simulated soil water content had the same trend as the measured one. The statistical evaluation results for model performance in MAE, NRMSE, and NSE are summarized in Table 4. For the calibration analysis, the MAE and NRMSE values for soil water content were between 0.009 and $0.022 \mathrm{~cm}^{3} / \mathrm{cm}^{3}$ and between 0.048 and 0.089 , respectively. For the validation analysis, the MAE and NRMSE values in MRT were between 0.008 and $0.018 \mathrm{~cm}^{3} / \mathrm{cm}^{3}$ and between 0.046 and 0.085 , respectively, and the $M A E$ and NRMSE values in MBF were between 0.009 and $0.019 \mathrm{~cm}^{3} / \mathrm{cm}^{3}$ and between 0.047 and 0.074 , respectively. The NSE values were in the range of 0.58 to 0.86 for flood irrigation, and 0.35 to 0.76 for mulched drip irrigation. The average values of MAE, NRMSE, and NSE for flood irrigation, 
MRT, and MBF were 0.014, 0.013, and $0.012 \mathrm{~cm}^{3} / \mathrm{cm}^{3}, 0.061,0.059$, and 0.055 , and 0.753, 0.614, 0.653, respectively. From the graphical and statistical results, the simulated and measured soil water content showed good agreement.

Table 3. The optimized soil hydraulic parameters used for the Hydrus-2D.

\begin{tabular}{|c|c|c|c|c|c|c|}
\hline $\begin{array}{c}\text { Depth } \\
\text { (cm) }\end{array}$ & $\begin{array}{c}\theta_{r} \\
\left(\mathrm{~cm}^{3} \cdot \mathrm{cm}^{-3}\right)\end{array}$ & $\begin{array}{c}\theta_{s} \\
\left(\mathrm{~cm}^{3} \cdot \mathrm{cm}^{-3}\right)\end{array}$ & $\begin{array}{c}\alpha \\
\left(\mathrm{cm}^{-1}\right)\end{array}$ & $n$ & $\begin{array}{c}K_{s} \\
\left(\mathrm{~cm} \cdot \mathrm{day}^{-1}\right)\end{array}$ & $l$ \\
\hline $0-40$ & 0.051 & 0.410 & 0.009 & 1.35 & 14.8 & 0.5 \\
\hline $40-80$ & 0.049 & 0.387 & 0.011 & 1.28 & 15.9 & 0.5 \\
\hline 80-150 & 0.045 & 0.331 & 0.015 & 1.31 & 25.7 & 0.5 \\
\hline $150-200$ & 0.044 & 0.333 & 0.02 & 1.31 & 23.4 & 0.5 \\
\hline$>200$ & 0.041 & 0.342 & 0.017 & 1.36 & 27.3 & 0.5 \\
\hline
\end{tabular}

Note: Saturated hydraulic conductivity $\left(K_{s}\right)$ and saturated water content $\left(\theta_{s}\right)$ were measured values, whereas $n, \alpha$, and $\theta_{r}$ were estimated values through inverse simulation, $l$ is a pore connectivity parameter which is normally set to 0.5 .
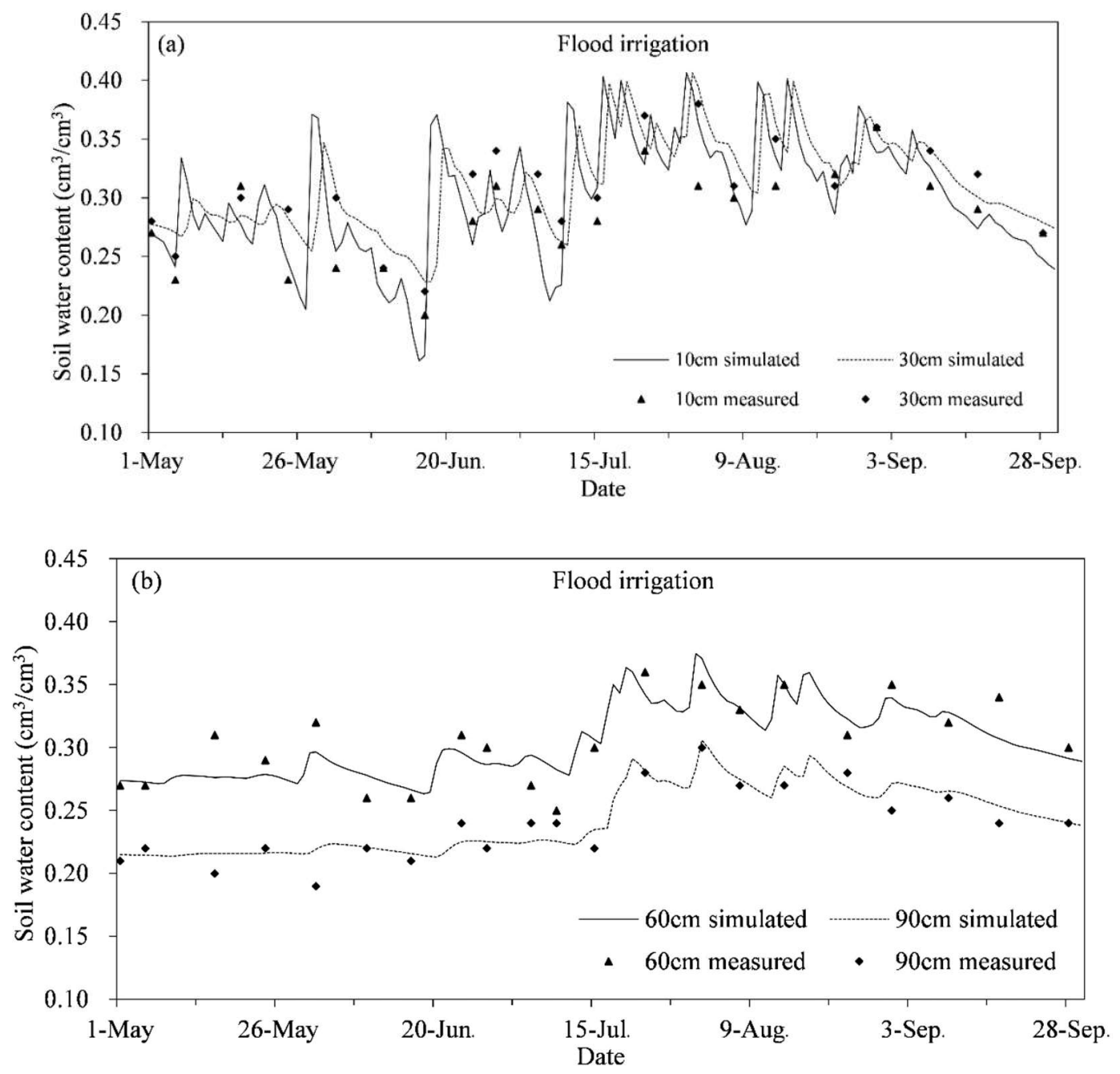

Figure 4. Cont. 

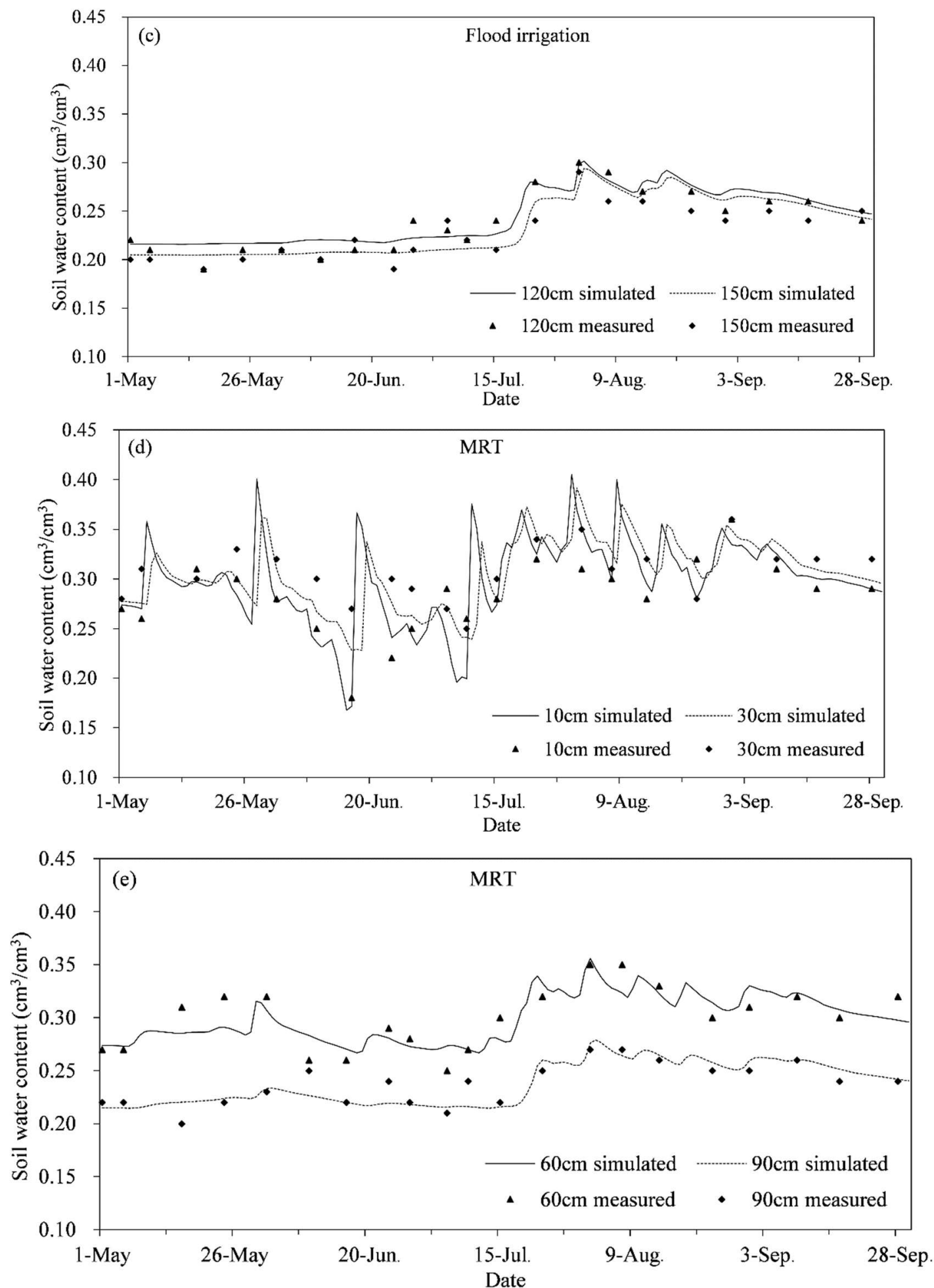

Figure 4. Cont. 

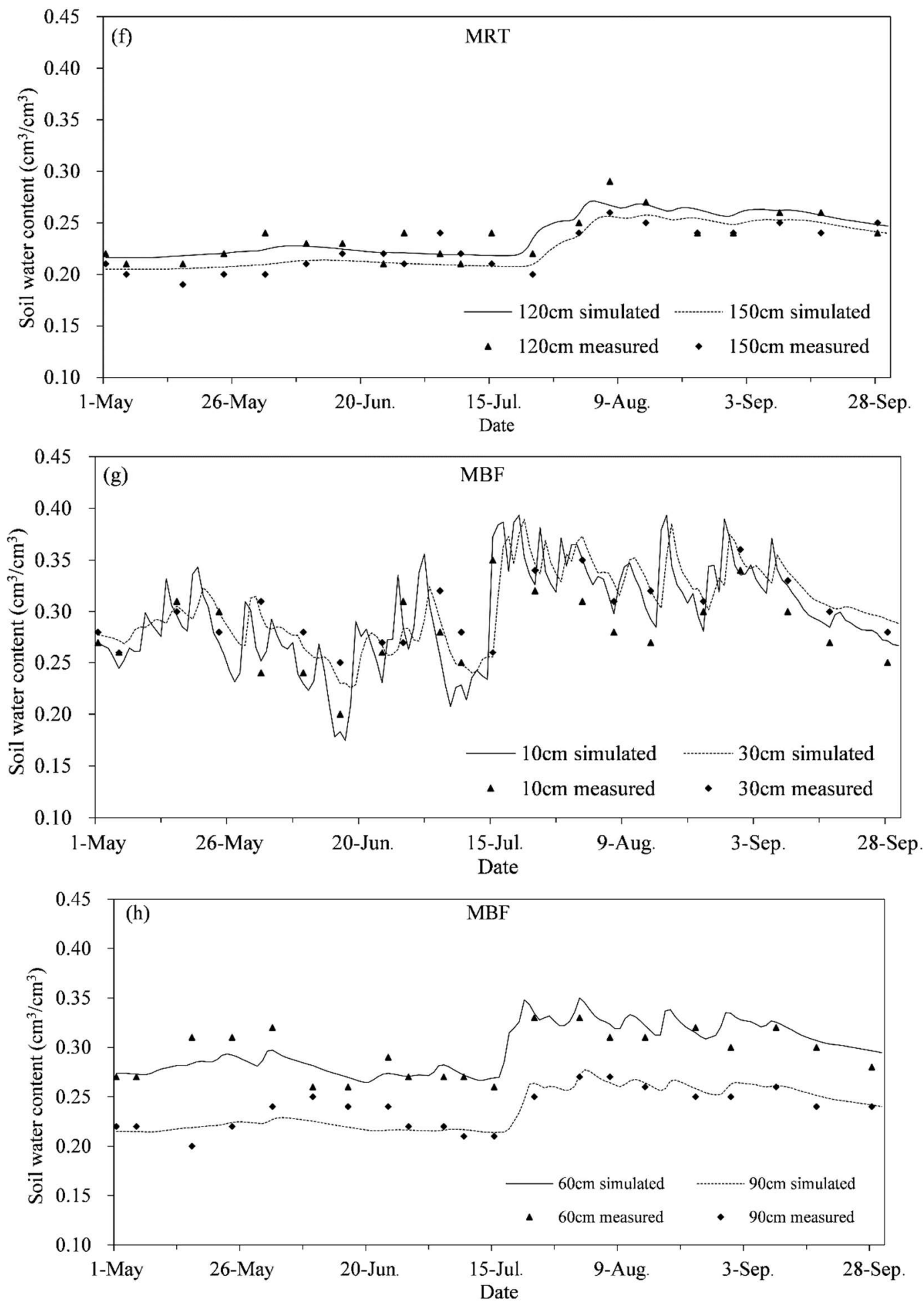

Figure 4. Cont. 


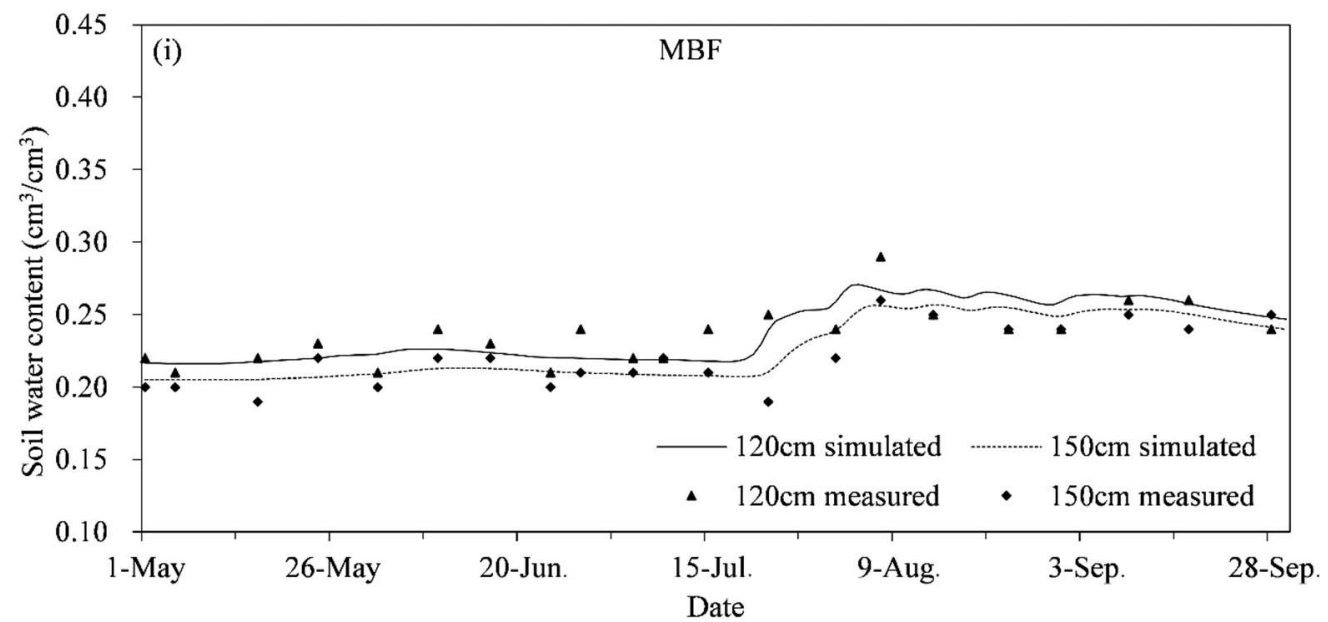

Figure 4. Simulated and measured soil water content at different soil depths under the two irrigation methods. (a-c): Soil water content under flood irrigation at 10, 30, 60, 90, 120, $150 \mathrm{~cm}$, respectively; (d-f): Soil water content of MRT under mulched drip irrigation at 10, 30, 60, 90, 120, $150 \mathrm{~cm}$, respectively; (g-i): Soil water content of MBF under mulched drip irrigation at 10, 30, 60, 90, 120, $150 \mathrm{~cm}$, respectively.

Table 4. MAE, NRMSE, and NSE between the simulated and measured soil water content at different soil depths.

\begin{tabular}{|c|c|c|c|c|c|c|c|c|c|}
\hline \multirow{3}{*}{$\begin{array}{l}\text { Soil } \\
\text { Depth } \\
\text { (cm) }\end{array}$} & \multirow{2}{*}{\multicolumn{3}{|c|}{ Flood Irrigation }} & \multicolumn{6}{|c|}{ Mulched Drip Irrigation } \\
\hline & & & & \multicolumn{3}{|c|}{ MRT } & \multicolumn{3}{|c|}{ MBF } \\
\hline & $\begin{array}{c}M A E \\
\left(\mathrm{~cm}^{3} / \mathrm{cm}^{3}\right)\end{array}$ & NRMSE & NSE & $\begin{array}{c}M A E \\
\left(\mathrm{~cm}^{3} / \mathrm{cm}^{3}\right)\end{array}$ & NRMSE & NSE & $\begin{array}{c}M A E \\
\left(\mathrm{~cm}^{3} / \mathrm{cm}^{3}\right)\end{array}$ & NRMSE & NSE \\
\hline 10 & 0.022 & 0.089 & 0.58 & 0.017 & 0.085 & 0.59 & 0.019 & 0.074 & 0.65 \\
\hline 30 & 0.015 & 0.056 & 0.83 & 0.018 & 0.071 & 0.35 & 0.012 & 0.050 & 0.76 \\
\hline 60 & 0.014 & 0.058 & 0.71 & 0.014 & 0.054 & 0.67 & 0.013 & 0.052 & 0.60 \\
\hline 90 & 0.010 & 0.052 & 0.81 & 0.008 & 0.047 & 0.67 & 0.009 & 0.050 & 0.65 \\
\hline 120 & 0.009 & 0.048 & 0.86 & 0.010 & 0.052 & 0.66 & 0.011 & 0.057 & 0.50 \\
\hline 150 & 0.012 & 0.062 & 0.72 & 0.008 & 0.046 & 0.75 & 0.009 & 0.047 & 0.76 \\
\hline
\end{tabular}

\subsection{Water Balance under Different Irrigation Methods}

The water balance of the simulation for flood irrigation and mulched drip irrigation is presented in Table 5. Compared with flood irrigation, the root water uptake under mulched drip irrigation was increased by approximately $6.1 \mathrm{~mm}$, whereas evaporation was significantly reduced by $70.4 \mathrm{~mm}$. There was also a significant difference between the drainage (bottom boundary), and the value of drainage under mulched drip irrigation was about 2.7 times that under flood irrigation. In general, it can be concluded that evaporation under mulched drip irrigation was obviously reduced, and the irrigation use efficiency could be effectively improved.

Table 5. Simulated water balance under flood irrigation and mulched drip irrigation.

\begin{tabular}{ccc}
\hline Water Balance Component $(\mathbf{m m})$ & Flood Irrigation & Mulched Drip Irrigation \\
\hline Root water uptake & 359.8 & 365.9 \\
Evaporation & 130.6 & 60.2 \\
Drainage & 55.8 & 20.4 \\
Storage Change & 128.1 & 75.3 \\
Irrigation & 381 & 228 \\
Rainfall & 297.7 & 297.7 \\
\hline
\end{tabular}




\subsection{Soil Water Movement Simulation during the Growing Season}

\subsubsection{Variations in Water Fluxes}

At the end of the simulation, the cumulative water fluxes were calculated at depths of 1.5, 2.0, 2.5, 3.0, 3.5, and $4.0 \mathrm{~m}$. The results are summarized in Figure 5. The cumulative water flux values under flood irrigation at these depths were 17.6, 15.7, 13.2, 10.6, 8.0, and $5.6 \mathrm{~cm}$, respectively; the cumulative water flux values under mulched drip irrigation were 9.6, 7.8, 5.8, 4.0, 2.7, and $2.0 \mathrm{~cm}$, respectively. At the depth of $1.5 \mathrm{~m}$, the cumulative water flux of flood irrigation was 1.8 times the value of mulched drip irrigation; at the depth of $3.0 \mathrm{~m}$, the cumulative water flux value of flood irrigation was 2.7 times the value of mulched drip irrigation. The results indicated that the cumulative water fluxes under mulched drip irrigation and flood irrigation decreased as depth increased, and the values of flood irrigation were obviously greater than the values of mulched drip irrigation.

In this study, the simulation period was from maize planting to maize harvesting. The above data were the results of the end of the simulation. After the maize was harvested, soil water movement did not stop immediately. Soil water continued to move downwards under the water potential difference. However, irrigation ceased and precipitation decreased after the harvest of the maize, and the recharge of soil moisture from outside water was obviously reduced. Therefore, after harvesting, the difference in water fluxes between the two irrigation methods still showed the existing trend, that is, the values of the cumulative water flux under mulched drip irrigation were smaller than those of flood irrigation.

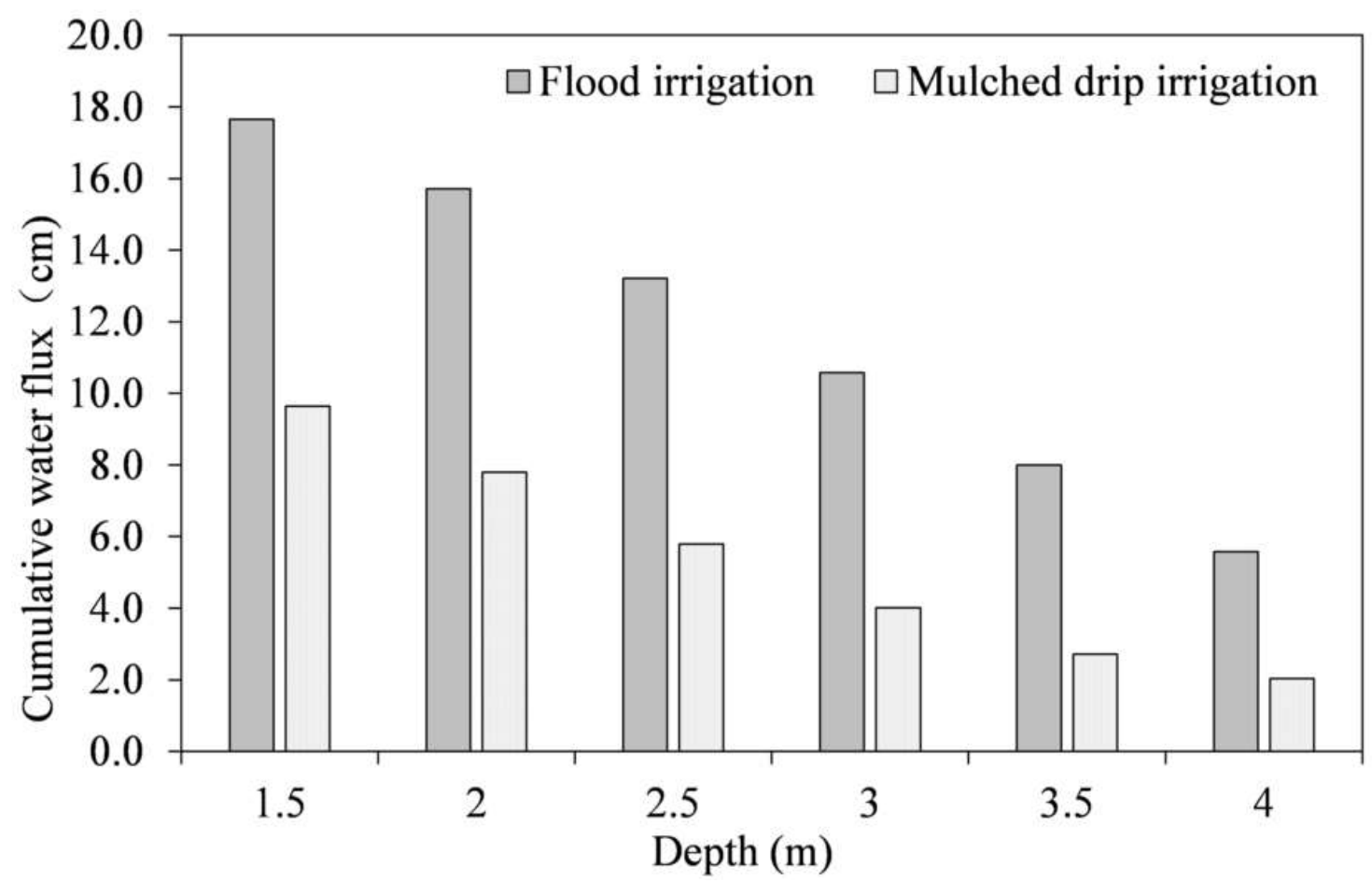

Figure 5. Cumulative water fluxes at different depths under mulched drip irrigation and flood irrigation.

\subsubsection{Variations in Infiltration Depth}

Different results of infiltration depth over time under mulched drip irrigation and flood irrigation are shown in Figure 6. On the 122nd day of the simulation, the infiltration depth under flood irrigation reached the maximum simulated depth $(400 \mathrm{~cm})$. At the same time, the infiltration depth under mulched drip irrigation was $325 \mathrm{~cm}$, which was $75 \mathrm{~cm}$ smaller than the infiltration depth under flood irrigation. According to the differences in infiltration depth under the two irrigation 
methods, the infiltration process throughout the entire growing season could be generally divided into two stages.

Stage with no Significant Difference

This period started in May and ended in June. During this period, the infiltration depth under mulched drip irrigation and flood irrigation reached 155 and $150 \mathrm{~cm}$, respectively. The infiltration depths under the two irrigation methods were almost the same. For this stage, the soil water content under flood irrigation was less than the value under mulched drip irrigation. Compared with mulched drip irrigation, flood irrigation required more water to supplement the soil water deficit. Therefore, although the amount of irrigation under flood irrigation was larger than that of mulched drip irrigation, the difference of the water that continued to infiltrate under the two irrigation methods was small. Consequently, no obvious difference existed in the infiltration depths under the two irrigation methods.

\section{Stage with Significant Difference}

This period started in July and ended in September. During this period, the infiltration depth under mulched drip irrigation was obviously less than the value under flood irrigation. From 29 June to 1 September, the infiltration depth under mulched drip irrigation changed from $155 \mathrm{~cm}$ to $325 \mathrm{~cm}$, an increase of $170 \mathrm{~cm}$. The infiltration depth under flood irrigation changed from $150 \mathrm{~cm}$ to $400 \mathrm{~cm}$, which was an increase of $250 \mathrm{~cm}$. The increases in infiltration depth under the two irrigation methods were greater than those in the first stage. For this stage, the soil water content under mulched drip irrigation was less than the value under flood irrigation. Compared with flood irrigation, mulched drip irrigation needed more water to compensate for the soil water deficit. The amount of irrigation under mulched drip irrigation was also less than that of flood irrigation. Thus, the difference in infiltration depth under the two irrigation methods was considerable.

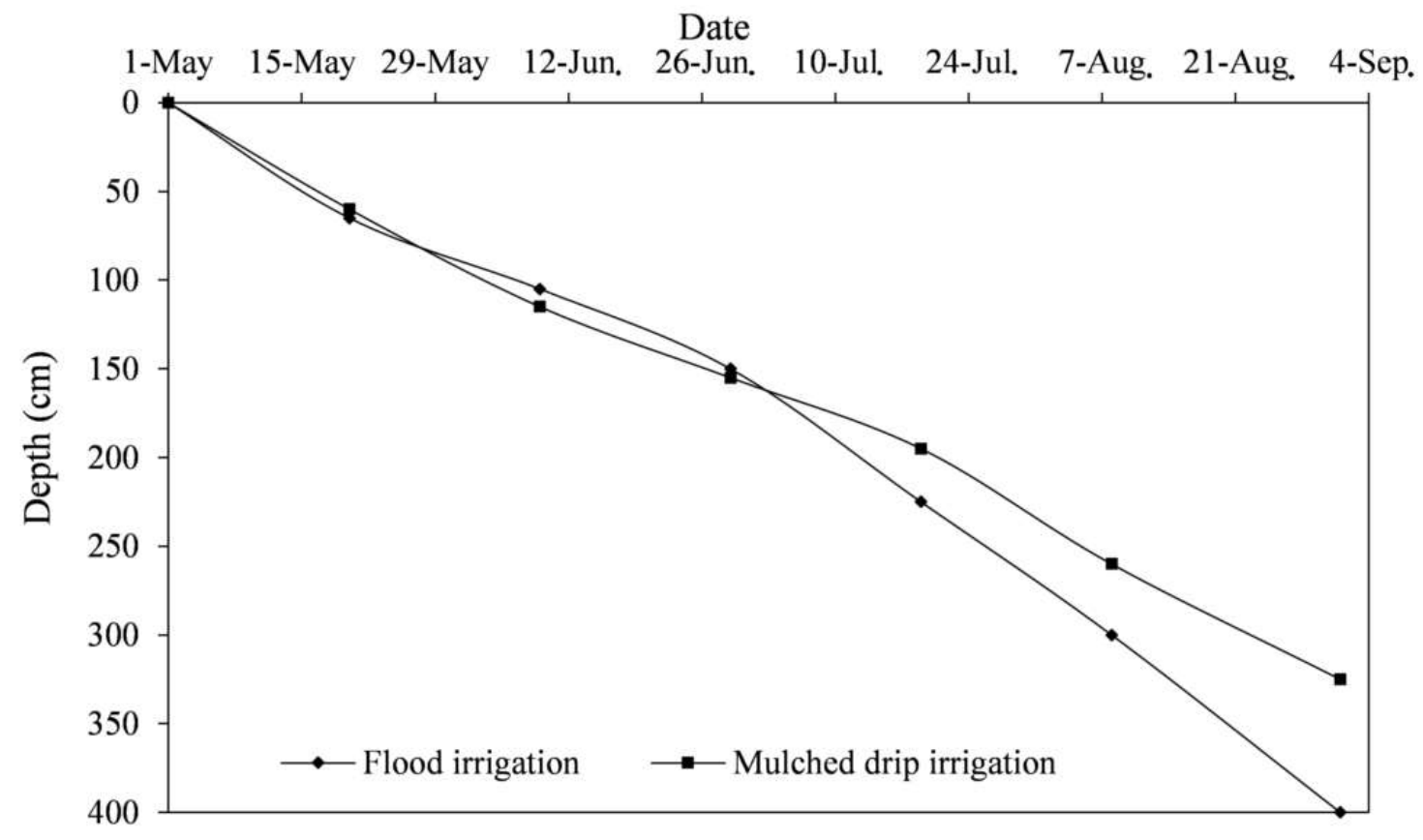

Figure 6. Infiltration depths at different times under mulched drip irrigation and flood irrigation. 


\section{Discussion}

\subsection{Effects of Mulched Drip Irrigation}

A relatively closed space was formed between the plastic film and the surface soil under mulched drip irrigation. The space changed the path of the water movement between the atmosphere and the soil. Film mulching influences the soil micro-environment by increasing soil heat flux in soil moisture dynamics [26,27]. Our results indicated that the effect of mulched drip irrigation on soil water content varied with the different growth stages of maize. In the initial growth stage, soil water content under mulched drip irrigation was larger than that of flood irrigation, indicating that the plastic film retained moisture [28], especially in the direct-influence zone of maize roots; that is, plastic films facilitated the conservation of soil water content, thereby enhancing the emergence rate and promoting seedling growth. However, in the main growth stage, the comparison between the soil water contents of the two irrigation methods showed the reverse. A similar phenomenon was also seen in the cultivation of potatoes with plastic film mulching, which showed a relatively low level of soil water content during the later growing season [29].

Mulched drip irrigation is a partial irrigation method that controls the irrigation amount, thereby preventing deep percolation [4]. Therefore, the irrigation return flow under mulched drip irrigation is reduced. Hu et al. [30] noted that, with the intensification of mulched drip irrigation, irrigation return flow dropped from $594.01 \mathrm{~mm}$ in the $1990 \mathrm{~s}$ to $164.62 \mathrm{~mm}$ in the 2010s. The reduction in irrigation return flow indicates a reduction in potential groundwater recharge, which leads to a decline in the groundwater table. The groundwater table declined by $0.54 \mathrm{~m}$ in a cotton field under mulched drip irrigation from 2012 to 2013 in the Kaidu-Kongqi River Basin [31]. Ming et al. [32] noted that the groundwater under mulched irrigation decreased from 2-3 to 5-6 $\mathrm{m}$ in a cotton field with the mulched drip irrigation method in Korla, Xinjiang from 2012 to 2016. The results of our study were in line with the above studies. In this study, the groundwater recharge was reflected by the water flux and infiltration depth. In the simulation results, the cumulative water fluxes at different depths and the final infiltration depths under mulched drip irrigation were less than those of flood irrigation. The groundwater recharge was reduced under mulched drip irrigation, and the groundwater table decreased accordingly.

\subsection{Implication for the Change in Irrigation Method}

To meet the challenges of water scarcity, irrigation methods have gradually changed from low-efficiency flood irrigation to high-efficiency irrigation technologies in the process of agricultural development [30]. Mulched drip irrigation has been promoted concentratedly in the Xiliao River Plain, replacing the traditional flood irrigation method. Given the improvement in irrigation efficiency and the increase in grain production, the implementation area of mulched drip irrigation has tended to increase gradually.

In the Xiliao River Plain, rivers have lost their capability to recharge groundwater due to interruption for many years [33]. Rainfall and irrigation return flow have become important sources of groundwater recharge. However, the results of our study indicated that mulched drip irrigation reduced rainfall infiltration depth and the groundwater recharge in irrigation areas to some extent. This phenomenon eventually lowers the groundwater table, thus threatening the stability of regional groundwater. The declining groundwater table is the limiting factor of sustainable agricultural development in the Xiliao River Plain. In addition, it should also be noted that the decline in the groundwater table will aggravate ecosystem degradation in the natural vegetation around the irrigated area [34], and increase the risk of land desertification.

\section{Conclusions}

This study investigated the variations in soil water content in an in situ experiment with mulched drip irrigation and flood irrigation in the Xiliao River Plain. Soil water movement in the entire growing 
season under the two irrigation methods was simulated by the Hydrus-2D model. The effect of mulched drip irrigation on soil water content varied with the different growth stages of maize. In the initial growth stage, the average soil water content under mulched drip irrigation was $2.03 \%$ larger than that of flood irrigation within $1 \mathrm{~m}$; at a depth of 100-150 cm, the soil water content under the two irrigation methods tended to be consistent. However, in the main growth stage, the soil water content along the $150 \mathrm{~cm}$ soil profile under mulched drip irrigation was lower than that under flood irrigation. The simulated results indicated that the cumulative water fluxes of flood irrigation were greater than the values of mulched drip irrigation. While the infiltration depth under flood irrigation reached the maximum simulated depth $(400 \mathrm{~cm})$, the infiltration depth under mulched drip irrigation was only $325 \mathrm{~cm}$. These results indicated that mulched drip irrigation reduced infiltration depth and the groundwater recharge to some extent in the Xiliao River Plain. Therefore, the implementation of mulched drip irrigation with maize should be rationally planned to preserve the stability of regional groundwater.

Author Contributions: Conceptualization, X.J. and M.C.; Methodology, Y.F.; Investigation, X.J. and L.Y.; Data Curation, F.W.; Writing-Original Draft Preparation, X.J.; Writing-Review and Editing, X.J. and M.C.

Funding: This research was funded by the Water Cycle and Water Ecological Security Study for the Semiarid Region, grant number (201501031).

Acknowledgments: We would like to acknowledge the Water Conservation Department for the research grant and financial support.

Conflicts of Interest: The authors declare no conflict of interest.

\section{References}

1. Han, M.; Zhao, C.Y.; Feng, G.; Yan, Y.Y.; Sheng, Y. Evaluating the effects of mulch and irrigation amount on soil water distribution and root zone water balance using Hydrus-2D. Water 2015, 7, 2622-2640. [CrossRef]

2. Wang, Z.M.; Jin, M.G.; Šimůnek, J.; Genuchten, M.T.V. Evaluation of mulched drip irrigation for cotton in arid northwest China. Irrig. Sci. 2014, 32, 15-27. [CrossRef]

3. Zhang, Y.Q.; Wang, J.D.; Gong, S.H.; Xu, D.; Sui, J.; Wu, Z.D.; Mo, Y. Effects of film mulching on evapotranspiration, yield and water use efficiency of a maize field with drip irrigation in northeastern China. Agric. Water Manag. 2018, 205, 90-99. [CrossRef]

4. Qin, S.J.; Li, S.E.; Kang, S.Z.; Du, T.S.; Tong, L.; Ding, R.S. Can the drip irrigation under film mulch reduce crop evapotranspiration and save water under the sufficient irrigation condition? Agric. Water Manag. 2016, 177, 128-137. [CrossRef]

5. Zhang, G.Q.; Liu, C.W.; Xiao, C.H.; Xie, R.Z.; Ming, B.; Hou, P.; Liu, G.Z.; Xu, W.J.; Shen, D.P.; Wang, K.R.; et al. Optimizing water use efficiency and economic return of super high yield spring maize under drip irrigation and plastic mulching in arid areas of China. Field Crops Res. 2017, 211, 137-146. [CrossRef]

6. Chakraboyty, D.; Nagarajan, S.; Aggarwal, P.; Gupta, V.K.; Tomar, R.K.; Garg, R.N.; Sahoo, R.N.; Sarkar, A.; Chopra, U.K.; Sarma, K.S.S.; et al. Effect of mulching on soil and plant water status: and the growth and yield of wheat (Triticum aestivum L.) in a semi-arid environment. Agric. Water Manag. 2008, 95, 1323-1334. [CrossRef]

7. Zhou, L.M.; Li, F.M.; Jin, S.L.; Song, Y.J. How two ridges and the furrow mulched with plastic film affect soil water: Soil temperature and yield of maize on the semiarid Loess Plateau of China. Field Crops Res. 2009, 113, 41-47. [CrossRef]

8. Han, D.M.; Zhou, T.T. Soil water movement in the unsaturated zone of an inland arid region: Mulched drip irrigation experiment. J. Hydrol. 2018, 559, 13-29. [CrossRef]

9. Selim, T.; Bouksila, F.; Berndtsson, R.; Persson, M. Soil water and salinity distribution under different treatments of drip irrigation. Soil Sci. Soc. Am. J. 2013, 77, 1144-1156. [CrossRef]

10. Qi, Z.J.; Feng, H.; Zhao, Y.; Zhang, T.B.; Yang, A.Z.; Zhang, Z.X. Spatial distribution and simulation of soil moisture and salinity under mulched drip irrigation combined with tillage in an arid saline irrigation district, Northwest China. Agric. Water Manag. 2018, 201, 219-231. [CrossRef]

11. Cetin, M.; Kirda, C. Spatial and temporal changes of soil salinity in a cotton field irrigated with low-quality water. J. Hydrol. 2003, 272, 238-249. [CrossRef] 
12. Ngouajio, M.; Wang, G.; Goldy, R. Withholding of drip irrigation between transplanting and flowering increases the yield of field-grown tomato under plastic mulch. Agric. Water Manag. 2007, 87, 285-291. [CrossRef]

13. Wang, F.X.; Wu, X.X.; Shock, C.C.; Chu, L.Y.; Gu, X.X.; Xue, X. Effects of drip irrigation regimes on potato tuber yield and quality under plastic mulch in arid northwestern China. Field Crop Res. 2011, 122, 78-84. [CrossRef]

14. Wei, Q.; Hu, C.S.; Oenema, O. Soil mulching significantly enhances yields and water and nitrogen use efficiencies of maize and wheat: A meta-analysis. Sci. Rep. 2015, 5, 16-21. [CrossRef]

15. Reyes-Cabrera, J.; Zotarelli, L.; Dukes, M.D.; Rowland, D.L.; Sargent, S.A. Soil moisture distribution under drip irrigation and seepage for potato production. Agric. Water Manag. 2016, 169, 183-192. [CrossRef]

16. Luo, S.S.; Zhu, L.; Liu, J.L.; Bu, L.D.; Yue, S.C.; Shen, Y.F.; Li, S.Q. Sensitivity of soil organic carbon stocks and fractions to soil surface mulching in semiarid armland. Eur. J. Soil Biol. 2015, 67, 35-42. [CrossRef]

17. Whalley, W.R. Considerations on the use of time-domain reflectometry (TDR) for measuring soil water content. Eur. J. Soil Sci. 2010, 44, 1-9. [CrossRef]

18. Evett, S.R.; Parkin, G.W. Advances in soil water content sensing: The continuing maturation of technology and theory. Vadose Zone J. 2005, 4, 986-991. [CrossRef]

19. Wang, P.; Song, X.F.; Han, D.M.; Zhang, Y.H.; Liu, X. A study of root water uptake of crops indicated by hydrogen and oxygen stable isotopes: A case in Shanxi Province, China. Agric. Water Manag. 2010, 97, 475-482. [CrossRef]

20. Richards, L. Capillary conduction of liquid in porous media. Physics 1931, 1, 318-333. [CrossRef]

21. Feddes, R.A.; Kowalik, P.J.; Zaradny, H. Simulation of Field Water Use and Crop Yield; John Wiley \& Sons: New York, NY, USA, 1978.

22. Vrugt, J.A.; Hopmans, J.W.; Šimunek, J. Calibration of a two-dimensional root water uptake model. Fluid Phase Equilib. 2001, 65, 1027-1037. [CrossRef]

23. Allen, R.G.; Pereira, L.S.; Smith, M.; Raes, D.; Wright, J.L. Fao-56 dual crop coefficient method for estimating evaporation from soil and application extensions. J. Irrig. Drain. Eng. 2005, 131, 2-13. [CrossRef]

24. Van Genuchten, M.T. A closed-form equation for predicting the hydraulic conductivity of unsaturated soils. Soil Sci. Soc. Am. J. 1980, 44, 892-898. [CrossRef]

25. Mualem, Y. A new model for predicting the hydraulic conductivity of unsaturated porous media. Water Resour. Res. 1976, 12, 513-522. [CrossRef]

26. Feng, Y.; Gong, D.Z.; Mei, X.R.; Hao, W.P.; Tang, D.H.; Cui, N.B. Energy balance and partitioning in partial plastic mulched and non-mulched maize fields on the Loess Plateau of China. Agric. Water Manag. 2017, 191, 193-206. [CrossRef]

27. Li, X.Y.; Shi, H.B.; Šimůnek, J.; Gong, X.W.; Peng, Z.Y. Modeling soil water dynamics in a drip-irrigated intercropping field under plastic mulch. Irrig. Sci. 2015, 33, 289-302. [CrossRef]

28. Liu, Y.; Li, Y.F.; Li, J.S.; Yan, H.J. Effects of mulched drip irrigation on water and heat conditions in field and maize yield in sub-humid region of northeast China. Trans. Chin. Soc. Agric. Mach. 2015, 46, 93-104. (In Chinese) [CrossRef]

29. Zhao, H.; Xiong, Y.C.; Li, F.M.; Wang, R.Y.; Qiang, S.C.; Yao, T.F.; Mo, F. Plastic film mulch for half growing-season maximized wue and yield of potato via moisture-temperature improvement in a semi-arid agroecosystem. Agric. Water Manag. 2012, 104, 68-78. [CrossRef]

30. Hu, Q.L.; Yang, Y.H.; Han, S.M.; Yang, Y.M.; Ai, Z.P.; Wang, J.S.; Ma, F.Y. Identifying changes in irrigation return flow with gradually intensified water-saving technology using hydrus for regional water resources management. Agric. Water Manag. 2017, 194, 33-47. [CrossRef]

31. Zhang, Z.; Hu, H.; Tian, F.; Yao, X.; Sivapalan, M. Groundwater dynamics under water saving irrigation and implications for sustainable water management in an oasis: Tarim river basin of western China. Hydrol. Earth Syst. Sci. 2014, 18, 3951-3967. [CrossRef]

32. Ming, G.H.; Tian, F.Q.; Hu, H.C. Effect of water table depth on soil water and salt dynamics and soil salt accumulation characteristics under mulched drip irrigation. Trans. Chin. Soc. Agric. Eng. 2018, 34, 90-97. (In Chinese with English Abstract) [CrossRef]

33. Yang, H.S.; Liu, J.; Liang, H.Y. Change characteristics of climate and water resources in West Liaohe River Plain. Chin. J. Appl. Ecol. 2009, 20, 84-90. (In Chinese with English Abstract) [CrossRef] 
34. Ren, D.Y.; Xu, X.; Engel, B.; Huang, G.H. Growth responses of crops and natural vegetation to irrigation and water table changes in an agro-ecosystem of Hetao, upper yellow river basin: Scenario analysis on maize, sunflower, watermelon and tamarisk. Agric. Water Manag. 2018, 199, 93-104. [CrossRef]

(C) 2018 by the authors. Licensee MDPI, Basel, Switzerland. This article is an open access article distributed under the terms and conditions of the Creative Commons Attribution (CC BY) license (http://creativecommons.org/licenses/by/4.0/). 